reinforcement corrosion [6]. A comparison between the Persian Gulf and other marine environments shows the severity of the harsh condition in this region. The amount of various compounds in the Persian Gulf compared to other seawaters is given in Table 1. Specifically, the value of chloride and sulfate ions in this seawater is reported as 23,300 PPM and 3264 PPM, respectively, which are higher than many other seawaters $[7,8]$. These harmful ions in combination with other factors such as high temperature, humidity, tidal effects, and UV radiation degrade the durability of concrete structures in this area [9-12].

Although preventing the corrosion of reinforced concrete structures starts from the design phase, there are some complementary methods recommended to increase the lifetime of these structures, such as application of coatings [4]. Among the various types of coatings, organic and inorganic ones are widely used for utilization on concrete surfaces due to their flexibility, appropriate adhesion, and ease of application [13, 14]. However, durability of these coatings in the aggressive environments influences their lifetime [15]. Thus, cement-based coatings containing pozzolanic materials, and geopolymer-based coatings have been proposed as viable alternatives to the common coatings, particularly, in the harsh environmental conditions, owing to the low permeability and excellent adhesion of these materials [16-18].

Shekarchi et al. examined different types of coatings produced with $25 \%$ ground-granulated blast-furnace slag (GGBFS) and 7.5\% microsilica to protect the concrete structures in the real environment of the Persian Gulf [19]. The results indicated that the highest short-term strength was achieved for using microsilica, and the highest long-term strength was obtained for both microsilica and GGBFS. Also, the lowest water absorption was achieved in the mixtures containing $25 \%$ GGBFS and $7.5 \%$ microsilica.

It has been shown that geopolymers can attain superior mechanical properties, high resistances to chemical attack

Table 1 Compositions of seawaters in the Persian Gulf and other regions $[7,8]$

\begin{tabular}{llllll}
\hline & $\begin{array}{l}\text { Persian } \\
\text { Gulf }\end{array}$ & $\begin{array}{l}\text { Atlantic } \\
\text { Sea }\end{array}$ & $\begin{array}{l}\text { North } \\
\text { Sea }\end{array}$ & $\begin{array}{l}\text { Mediter- } \\
\text { ranean } \\
\text { Sea }\end{array}$ & Baltic Sea \\
\hline $\mathrm{Na}^{+}$ & 12,400 & 9950 & 11,050 & 11,560 & 4980 \\
$\mathrm{~K}^{+}$ & 450 & 430 & 400 & 420 & 180 \\
$\mathrm{Mg}^{2+}$ & 1460 & 1500 & 1330 & 1780 & 600 \\
$\mathrm{Ca}^{2+}$ & 430 & 410 & 430 & 470 & 190 \\
$\mathrm{Cl}^{-}$ & 23,300 & 17,830 & 19,890 & 21,380 & 8960 \\
$\mathrm{SO}_{4}^{2-}$ & 3264 & 2540 & 2780 & 3060 & 1250 \\
$\begin{array}{l}\text { Salt (g/ } \\
\text { liter) }\end{array}$ & 38.9 & 32.6 & 35.9 & 38.7 & 16.2 \\
\hline
\end{tabular}

SN Applied Sciences and fire, and long service life [20-24]. Zhang et al. examined the microstructure and feasibility of using geopolymer coatings containing $90 \%$ metakaolin and $10 \%$ GGBFS in marine environments [16]. The lower permeability, higher adhesion, and superior anticorrosive properties for geopolymer coatings were reported by the authors. In another study with the same materials [17], the low permeability of geopolymer coatings was considered as the main factor for its superior performance compared to the OPC coatings. Indeed, the permeability of coating mortars is attributed to the amount of pores larger than $50 \mathrm{~nm}$, while in the geopolymer coatings $94 \%$ of pores are smaller than $20 \mathrm{~nm}$, and in OPC coating, $73.7 \%$ of pores are larger than $50 \mathrm{~nm}$. Temuujin et al. found that the adhesion strength of geopolymer coatings produced with metakaolin was higher compared to the OPC, and its value is highly dependent on the SI to Al ratio [25]. Further, Ramezanianpour et al. indicated that the addition of $2 \%$ nanosilica is significantly effective in improving the flowability, compressive strength, and chloride resistance of alkali-activated slag mortars [26]. Thus, it can be seen that geopolymer coatings and cement-based coatings modified with pozzolanic materials can be considered as an effective solution against the corrosion of concrete structures in the marine environment.

\section{Research objectives and scope}

A few studies were conducted on the cement-based and geopolymer-based coatings and the comparison between their protections, particularly, in the marine environment. The purpose of this study is to evaluate and compare the optimum mix design of cement-based and geopolymerbased coatings in terms of durability and mechanical properties. The first important point of this research is the use of a special marine artificial environment which can simulate the harsh condition of the Persian Gulf with the highest accuracy and degree of adaptation to place the samples in. Further, the use of siliceous aggregates with a maximum size of one millimeter made it possible to apply very thin coatings (about $5 \mathrm{~mm}$ ) which can result in a significant reduction in the use of materials. Also, pozzolanic materials applied in this study, known as GGBFS and silica fume, are industrial by-products which are available and cost-effective materials inside the country. Thus, the possible promising results of this research can be considered as a step forward in the implementation of coatings for protecting the concrete structures around the marine environment of the Persian Gulf in Iran. 


\section{Materials, methods, and mix design}

In this section, all the materials applied in this study are described by details. Further, the mix design procedure and test methods are discussed considering the related standards and requirements. Figure 1 presents a flowchart of the experimental design of this study.

\subsection{Materials}

ASTM C150 [27] Type II Portland cement was used in this study. This is proposed by the code of practice for concrete durability in the Persian Gulf and Oman Sea [28]. Table 2 shows the chemical compositions of the cement and the corresponding threshold values according to the ASTM C150 [27] and Iran 389 standards [29]. Based on the chemical compositions and Bogue equations, the values of C3S, $\mathrm{C} 2 \mathrm{~S}, \mathrm{C} 3 \mathrm{~A}$, and $\mathrm{C} 4 \mathrm{AF}$ were determined to be $48.7 \%, 28.1 \%$, $5 \%$, and $10.7 \%$ in total mass, respectively.

Further, the normal consistency of hydraulic cement test, ASTM C187 [30], time of setting test, ASTM C191 [31], cement density test, ASTM C188 [32], fineness of hydraulic cement test, ASTM C204 [33], and compressive strength test, ASTM C109 [34] were conducted on the cement specimens and the results are given in Table 3 .

The ground-granulated blast-furnace slag (GGBFS), which is called in the short form of slag in the following, was procured from a local company and classified as grade 80 in the strength specification of the ASTM C989 [35]. The chemical compositions and physical properties of the slag are given in Tables 2 and 4. Further, the $\mathrm{X}$-ray diffraction (XRD) test was performed to assess the amorphous characteristics of this additive. The $3 \%$ level of crystallinity showed that the slag used in this research was mostly in amorphous phase.

Silica fume is another Pozzolanic material that was used in this study. It contains very small-sized particles that are rich in $\mathrm{SiO} 2$ and works as an extremely reactive pozzolanic material [37]. The chemical and physical characteristics of these materials, as well as minimum requirements based on ASTM C1240 [36], are indicated in Tables 2 and 4.

In this study, the siliceous aggregates consisting of silica, granite, and sandstone were used for the concrete mixture preparation. The aggregates had a specific gravity of $2.64 \mathrm{~g} / \mathrm{cm}^{3}\left(2640 \mathrm{~kg} / \mathrm{m}^{3}\right)$ and water absorption of $1.01 \%$. The graphs of aggregate gradation with higher and lower limits based on the ASTM C778 [38] are presented in Fig. 2.

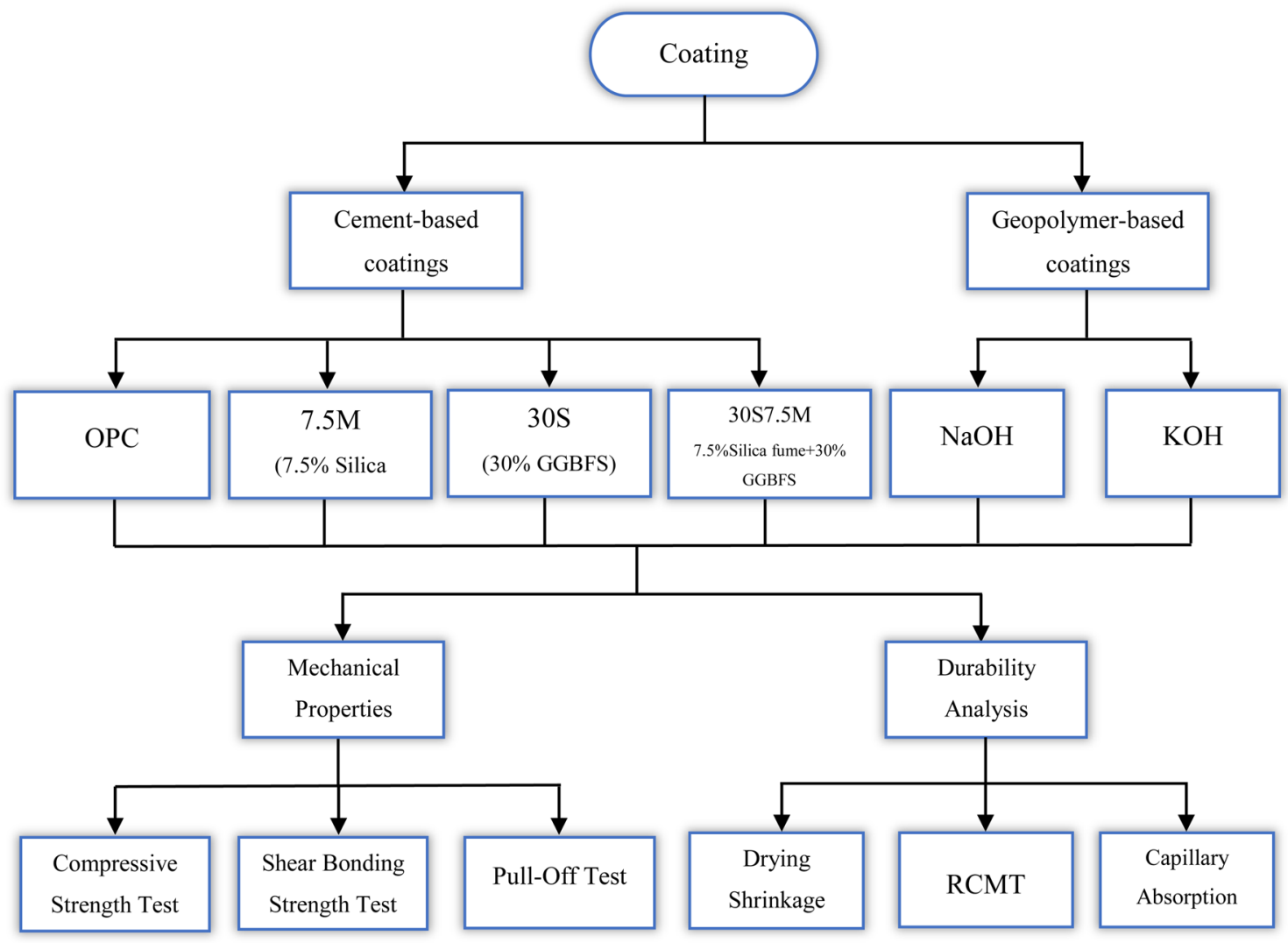

Fig. 1 The flowchart of the experimental design 
Table 2 Chemical characteristics and standard values of binders

\begin{tabular}{lcllc}
\hline Materials & Cement (\%) & $\begin{array}{l}\text { Requirements for cement } \\
\text { (ASTM C150 [27]) }\end{array}$ & GGBFS (\%) & Silica fume (\%) \\
\hline $\mathrm{SiO}_{2}$ & 22.57 & $20<$ & 37.21 & 94.3 \\
$\mathrm{Al}_{2} \mathrm{O}_{3}$ & 4.12 & $6>$ & 11.56 & 1.1 \\
$\mathrm{Fe}_{2} \mathrm{O}_{3}$ & 3.51 & $6>$ & 1.01 & 0.7 \\
$\mathrm{CaO}$ & 63.22 & - & 36.75 & 0.49 \\
$\mathrm{MgO}$ & 2.7 & $5>$ & 8.52 & 0.87 \\
$\mathrm{SO}_{3}$ & 1.5 & $3>$ & - & - \\
$\mathrm{S}$ & - & - & 0.968 & - \\
$\mathrm{Na}_{2} \mathrm{O}$ & 0.18 & - & 0.61 & 0.42 \\
$\mathrm{~K}_{2} \mathrm{O}$ & 0.54 & - & 0.7 & 1.32 \\
$\mathrm{TiO}_{2}$ & - & - & 1.23 & - \\
$\mathrm{MnO}$ & - & - & 0.986 & - \\
$\mathrm{P}_{2} \mathrm{O}_{5}$ & - & - & 0.032 & - \\
$\mathrm{L}_{0} \mathrm{O} . \mathrm{I}$ & - & - & 0.02 & - \\
\hline
\end{tabular}

Table 3 Cement characteristics

\begin{tabular}{|c|c|c|c|}
\hline- & & $\begin{array}{l}\text { Iran } 389 \text { Standard } \\
\text { requirements [29] }\end{array}$ & Used cement \\
\hline Fineness $\left(\mathrm{cm}^{2} / \mathrm{g}\right)$ & & 2800 & 2962 \\
\hline \multirow{2}{*}{ Minimum Compressive Strength $\left(\mathrm{kg} / \mathrm{cm}^{2}\right)$} & Age 7 & 170 & 211 \\
\hline & Age 28 & 280 & 350 \\
\hline Minimum time of setting (min) & & 45 & 157 \\
\hline Maximum time of setting (min) & & 375 & 225 \\
\hline Specific gravity $\left(\mathrm{gr} / \mathrm{cm}^{3}\right)$ & & - & 3.14 \\
\hline
\end{tabular}

Table 4 Physical properties of silica fume and GGBFS

\begin{tabular}{llll}
\hline & $\begin{array}{l}\text { Requirement } \\
\text { of ASTM C1240 } \\
{[36]}\end{array}$ & Silica fume & GGBFS \\
\hline Humidity (\%) & $6>$ & 1.5 & - \\
$\begin{array}{l}\text { L.O.I } \\
\text { Remaining on sieve No. }\end{array}$ & $6>$ & 0.1 & 0.02 \\
$\quad 10$ & 0.3 & - \\
$\begin{array}{l}\text { Passed from 45-micron } \\
\text { sieve (\%) }\end{array}$ & - & - & 83.39 \\
$\begin{array}{l}\text { Fineness based on BET } \\
\text { (m²/gr( }\end{array}$ & $15<$ & 19.2 & 0.3383 \\
$\begin{array}{l}\text { Accelerated pozzolanic } \\
\text { activity/control in 7 days } \\
\text { (\%) }\end{array}$ & $105<$ & 145 & 75 \\
Specific gravity (gr/cm ${ }^{3}$ ) & - & & \\
\hline
\end{tabular}

The activation process of pozzolanic materials was performed by a mixture of Sodium Hydroxide $(\mathrm{NaOH})$ or Potassium Hydroxide $(\mathrm{KOH})$ and Sodium Silicate $\left(\mathrm{Na}_{2} \mathrm{SiO}_{3}\right)$ solution. $\mathrm{KOH}$ and $\mathrm{NaOH}$ solutions are two commonly used alkali activators known as cost-effective, available, and sustainable materials for alkali-activated mortars

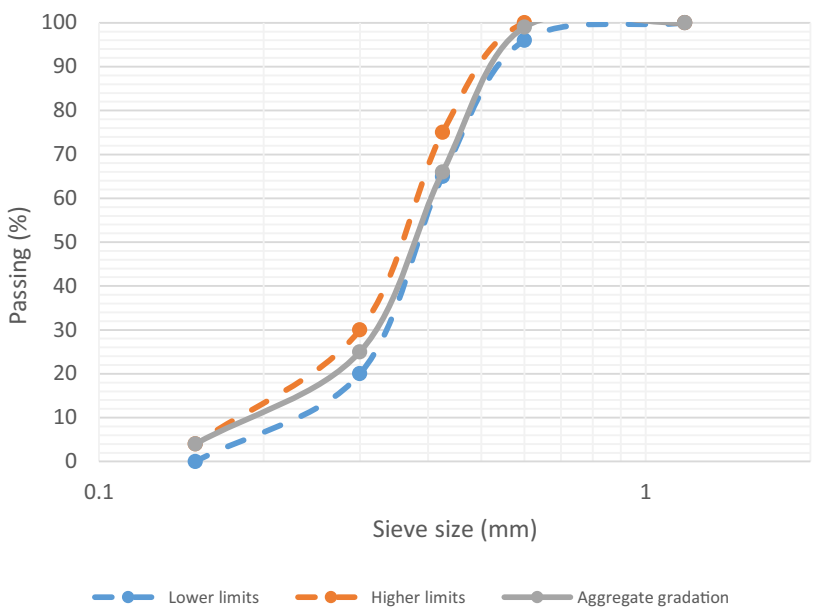

Fig. 2 The gradation of siliceous aggregates with higher and lower limits

$[26,39]$. Based on previous studies, the optimum ratio of Sodium Silicate was chosen to be 2.33 , and the concentration of $\mathrm{NaOH} / \mathrm{KOH}$ solutions was selected to be 6 molar (M) $[39,40]$. Accordingly, The $\mathrm{NaOH}$ and $\mathrm{KOH}$ pellets with a purity of $97 \%$ were added to water in order to 
Table 5 Properties of the superplasticizer used in this study

\begin{tabular}{ll}
\hline Chemical structure & $\begin{array}{l}\text { Modified poly- } \\
\text { carboxylate } \\
\text { ether }\end{array}$ \\
\hline lonic character & Anionic \\
Color & Dark Green \\
Physical state & Liquid \\
Chloride content & Max 500 ppm \\
Specific gravity & $1.1 \mathrm{~kg}$ per Liter \\
\hline
\end{tabular}

attain a $6 \mathrm{M}$ solution. To prepare the $\mathrm{KOH}$ solution with the specified concentration, solid $\mathrm{KOH}$ pellets were added to distilled water. This solution was used in mixtures 1 day after its preparation, in order to control the considerable heat released as a result of dissolution of alkali pellets in water [40-42]. $\mathrm{NaOH}$, as a solid and white substance with a boiling point of $1390^{\circ} \mathrm{C}$, melting point of $318^{\circ} \mathrm{C}$, and a density of $2.13 \mathrm{~g} / \mathrm{cm} 3$ was used in this study. Also, the boiling point, melting point, and density of $\mathrm{KOH}$ were $1327^{\circ} \mathrm{C}$, $398^{\circ} \mathrm{C}$, and $2.04 \mathrm{~g} / \mathrm{cm} 3$, respectively [43].

Another activator used in this study is sodium silicate (water glass) with the chemical formula $\mathrm{Na}_{2} \mathrm{SiO}_{3}$. Hydroxide-activated geopolymer composites have a more porous structure than silicate geopolymer compounds, so in the manufacturing procedure of geopolymer mortars, the combination of these two solutions has been used. Also, in terms of reducing soluble silicates, considering the fact that sodium silicate in powder form is less effective on the improvement of porosity, the sodium silicate solution was used in this study.

It should be noted that the ratio of $\mathrm{SiO}_{2}$ to $\mathrm{Na}_{2} \mathrm{O}$ in the mixtures was set to 2.33 , which is selected based on previous studies that evaluated the compressive strength of geopolymer paste samples with different silicates moduli [44]. Comparing the results of compressive strength tests on three water glass solutions with silicates moduli of 1.2, 2.33, and 3.3, we opt for the water glass with a silicate modulus of 2.33 due to its more favorable performance. Sodium silicate can increase the compressive strength of the alkaline activator solution (AAS) paste in two ways: first, it improves the dissolution rate of $\mathrm{Si}$ and $\mathrm{Al}$, and second, $\mathrm{Si}-\mathrm{O}$ bonds that form in the presence of sodium silicate are stronger than $\mathrm{Al}-\mathrm{O}$ bonds $[40,42,45,46]$.

A superplasticizer was used to achieve the required flow in cement-based mixtures, especially those containing silica fume. The properties of the superplasticizer used in the study are shown in Table 5.

\subsection{Specimen preparation}

The mixture proportions of different specimens are presented in Tables 6 and 7. Generally, four series of Portland cement-based mortars and two series of geopolymerbased mortars were prepared in this study.

The first group, called cement-based mortars, were produced at 0.33 water/cement ratio, while all the mixtures had a constant aggregates/binder ratio of 2 . The flowability of the fresh concrete mixes was determined through the flow-table test method conforming to ASTM C1437 [47]. Thus, the flow of all the mixtures was kept constant in the range of 150-190 mm using an adequate amount of superplasticizer.

The second group, called geopolymer-based mortars, was prepared with two different mix designs, in which the AAS was considered as the main variable. The molar concentration of sodium hydroxide and potassium hydroxide was kept $6 \mathrm{M}$ in both the geopolymer mixtures. The sodium silicate as the common part of the AAS was added

Table 6 Mix proportion of Portland cement-based concretes

\begin{tabular}{llllllll}
\hline Mix number & Mix ID & $\begin{array}{l}\text { Cement } \\
\left(\mathrm{kg} / \mathrm{m}^{3}\right)\end{array}$ & GGBFS $\left(\mathrm{kg} / \mathrm{m}^{3}\right)$ & $\begin{array}{l}\text { Silica fume } \\
\left(\mathrm{kg} / \mathrm{m}^{3}\right)\end{array}$ & Water $\left(\mathrm{kg} / \mathrm{m}^{3}\right)$ & $\begin{array}{l}\text { Aggregates } \\
\left(\mathrm{kg} / \mathrm{m}^{3}\right)\end{array}$ & $\begin{array}{l}\text { Superplasticizer } \\
(\mathrm{percent} \text { of binder })\end{array}$ \\
\hline 1 & OPC & 720 & 0 & 0 & 237.6 & 1440 & 0.8 \\
2 & $7.5 \mathrm{M}$ & 666 & 0 & 54 & 237.6 & 1440 & 1.1 \\
3 & 30S & 504 & 216 & 0 & 237.6 & 1440 & 0.8 \\
4 & 7.5M30S & 450 & 216 & 54 & 237.6 & 1440 & 1.1 \\
\hline
\end{tabular}

Table 7 Mix proportion of geopolymer-based concretes

\begin{tabular}{llllllll}
\hline Mix number & Mix ID Slag $\left(\mathrm{kg} / \mathrm{m}^{3}\right)$ & $\begin{array}{l}\text { Silica } \\
\text { fume } \\
\left(\mathrm{kg} / \mathrm{m}^{3}\right)\end{array}$ & $\begin{array}{l}\text { Alkali } \\
\text { activator } \\
\left(\mathrm{kg} / \mathrm{m}^{3}\right)\end{array}$ & Alkali activator type & $\begin{array}{l}\text { Water } \\
\text { glass } \\
\left(\mathrm{kg} / \mathrm{m}^{3}\right)\end{array}$ & $\begin{array}{l}\text { Aggre- } \\
\text { gates } \\
\left(\mathrm{kg} / \mathrm{m}^{3}\right)\end{array}$ \\
\hline 5 & $\mathrm{NaOH}$ & 440.8 & 23.2 & 198.85 & $\mathrm{NaOH} 6 \mathrm{M}$ & 79.15 & 1276 \\
6 & $\mathrm{KOH}$ & 440.8 & 23.2 & 198.85 & $\mathrm{KOH} 6 \mathrm{M}$ & 79.15 & 1276 \\
\hline
\end{tabular}


to activate the pozzolanic materials. In order to determine the required quantity of different ingredients in geopolymer mortars, the binder content was assumed to be constant. There were $440.8 \mathrm{~kg} / \mathrm{m}^{3}$ of slag and $23.2 \mathrm{~kg} / \mathrm{m}^{3}$ of silica fume in the mixtures, following previous studies [48, 49].

All the cubic and cylindrical specimens were cast in two and three layers, respectively; each layer was consolidated on a vibrating table to reduce the air voids. Then, to avoid rapid drying and eliminate shrinkage cracking, both geopolymer and cement-based specimens were kept under a wet towel in the laboratory for $24 \mathrm{~h}[26,50]$. After that, the demolded samples were cured in the Persian Gulf simulated environment until the test day.

\subsection{Test methods}

To evaluate the compressive strength of mortar mixtures, cube specimens of $50 \times 50 \times 50 \mathrm{~mm}$ were prepared and tested at $7,28,56$, and 90 days according to the ASTM C109 [34]. Three specimens of every mixture type at each age were tested and the mean value was reported as the compressive strength.

To determine the bond strength of the coating layer to the concrete, the shear bond strength test method was applied. The bond strength should be adequate to prevent any failure in the interface of samples. The roughness of the substrate surface and the type of repairing material play important roles on the bond properties [51]. In this method, firstly, concrete cube specimens with dimensions of $10 \times 15 \times 15 \mathrm{~cm}$ were made and then a $5-\mathrm{cm}$ layer of geopolymer mortar or cement mortar was applied on it. The shear strength would be determined by applying shear forces parallel to the interface. However, since the test specimen is produced with two parts, a bending moment may arise when the load is applied. Use of a test specimen consisting of three parts was suggested to solve this problem, although the main drawback of this method is the fact that two interfaces exist in this sample instead of one, and such a repairing system is not common in reality [52]. Thus, the guillotine method was proposed, in which a weight falls on the protruding part of the concrete in a two-part specimen and inhibits from the possible moment to arise. This method was conducted previously, and the results appeared to be promising [53]. Therefore, in this experiment, after 28,56, and 90 days of curing, the samples were loaded using a pressure jack, as shown in Fig. 3.

The tensile bond strength between the concrete surface and the coating mortar was determined through Pulloff test, according to EN 1542 [54]. The pull-off test method provides the most conservative bond strength evaluation, because it is only tensile load which is influential on the results, and other types of stresses are completely eliminated from the testing process [26]. Following this standard, the amount of force required to separate the coating mortar from the concrete surface is measured by the pulloff device (Fig. 4).

The drying shrinkage test, based on ASTM C596 [55], was performed to evaluate the durability characteristics of fabricated mortars. In this method, the shrinkage strain, normally the longitudinal strain, was measured at regular intervals of 7 days while the specimens were cured in the Persian Gulf simulated environment.

The rapid chloride migration test (RCMT) is one of the most widely used methods to evaluate the resistance of the mortars against chloride penetration, which was performed based on NT BUILD 492 [56]. It should be noted that in this test, chloride ions are assumed to be independent ions that do not interact with other ions. The test setup of RCMT is indicated in Fig. 5.
Fig. 3 Schematic of measuring adhesion resistance by twolevel cutting method
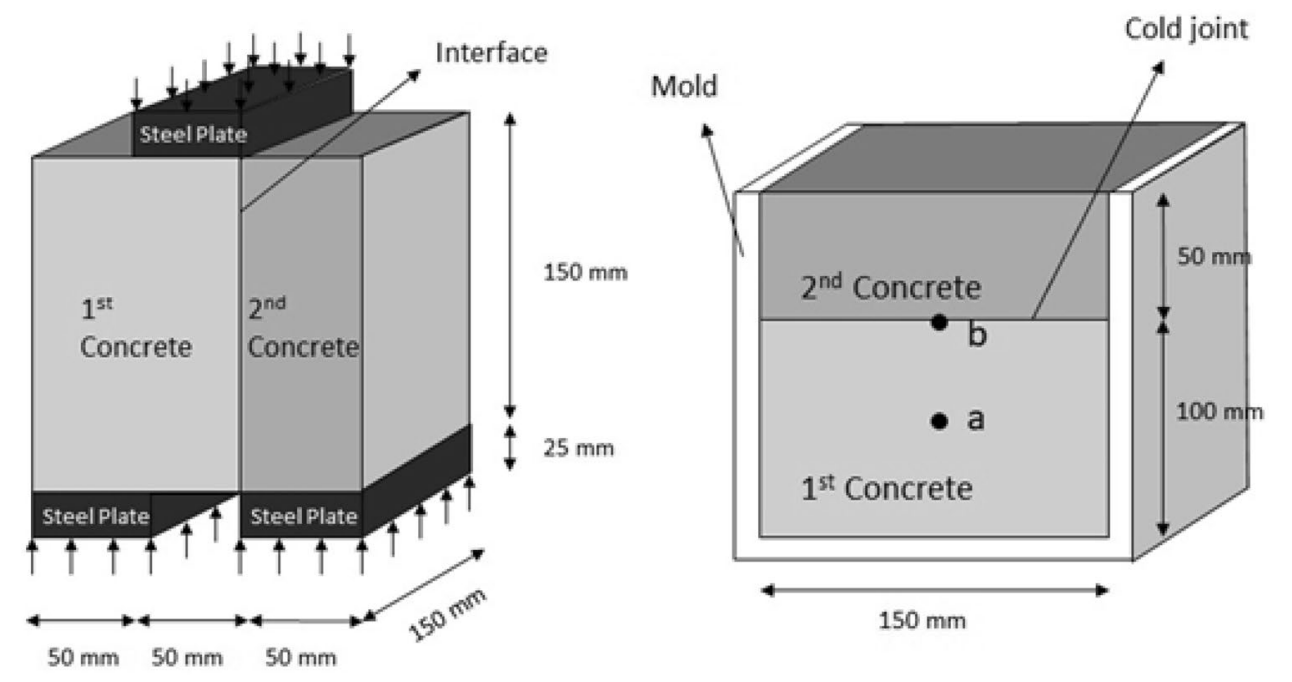
Fig. 4 The pull-off device applied in this study

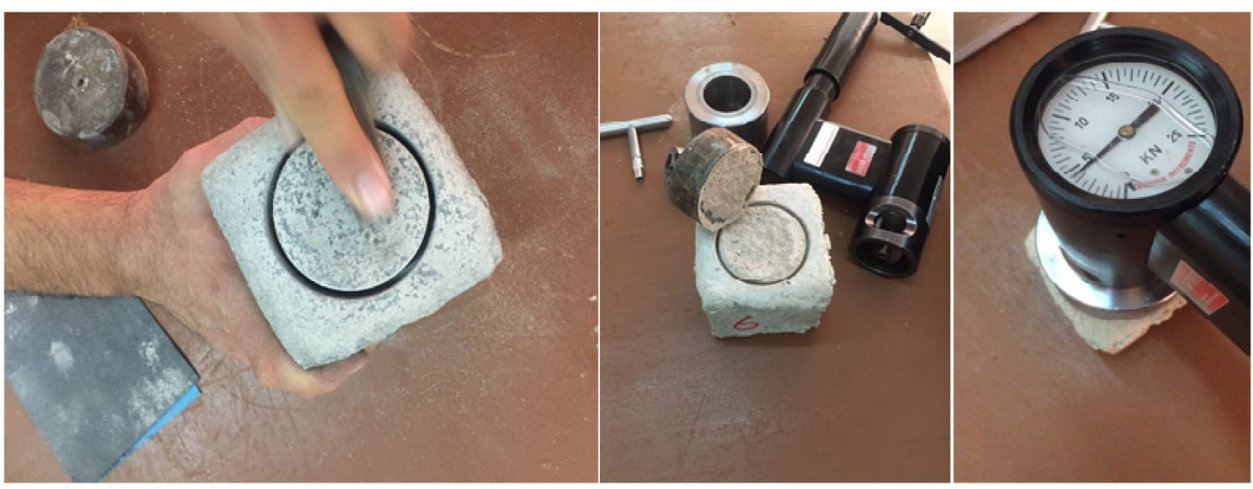

Fig. 5 The test setup of RCMT applied in this research

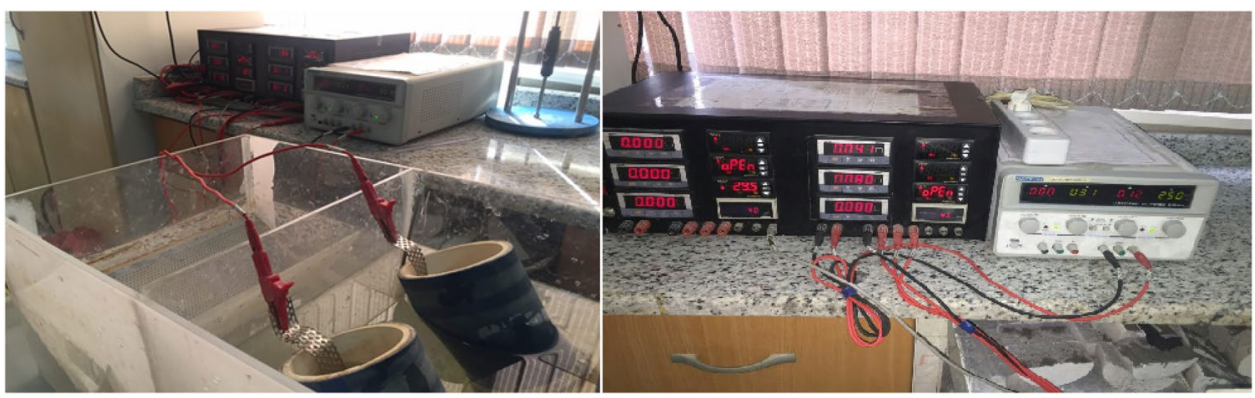

By recording the information obtained by RCMT device at the end of the test, the diffusion coefficient of chloride ions can be measured by Eq. 1:

$D_{\text {nssm }}=\frac{0.0239(273+T) L}{(U-2) t}\left(x_{d}-0.0238 \sqrt{\frac{(273+T) L x_{d}}{U-2}}\right)$,

where $D_{n s s m}$ is migration coefficient $\left(10^{-12} \mathrm{~m} / \mathrm{s}\right), U$ is voltage $(\mathrm{V}), T$ is the average of initial and final temperature of the solution $\left({ }^{\circ} \mathrm{C}\right), L$ is the sample thickness $(\mathrm{mm}), x_{d}$ is the average of penetration depth $(\mathrm{mm})$, and $t$ is the test duration (h).

The capillary absorption test, ASTM C1585 [57], was conducted to determine the increase in the mass of specimens resulted from water absorption. This evaluation is performed as a function of time while only one surface of the specimen is exposed to the water. To begin, the weights of the samples, which were located in the oven for 3 days at $50{ }^{\circ} \mathrm{C}$ were measured and reported. Subsequently, the weights of the same samples were measured after $1,3,6,24$, and $72 \mathrm{~h}$ of exposure to the water. Then, the water absorption was calculated according to Eq. 2:

$I=\frac{m_{t}}{a * d}$,

where $l$ is absorption $(\mathrm{mm}), m_{t}$ is the weight of the sample at $t(\mathrm{gr}), \mathrm{a}$ is the area of the cross section of the sample $\left(\mathrm{mm}^{2}\right)$, and dis the density of the sample $\left(\mathrm{gr} / \mathrm{mm}^{3}\right)$.

\subsection{Environmental condition}

The structures existing in the real condition of the coastal region in the south of Iran (Persian Gulf) are mostly in danger of deterioration, mainly due to the chloride-induced corrosion of steel bars. The specific environmental conditions of this area, such as high temperature and humidity, the tidal phenomenon of seawater, and UV radiations, are the main influential factors for intensifying the deterioration in the structures of this region. There were many studies performed to evaluate the effects of different factors separately $[9,58]$, however, regarding the simultaneous and intensifying effects of these factors on each other, it appears necessary to investigate them all at the same time.

The marine simulator designed and constructed at the Concrete Technology and Durability Research Center (CTDRC) at the Amirkabir University of Technology was utilized to accelerate the simulations of the coastal region in the south of Iran, as the case study in this research. Using this simulator environment was one of the unique parts of this study and made it possible to evaluate the combined effects of various deteriorative factors in a shorter amount of time, and increase the accuracy of the test results.

The interior view of the marine simulator, placement of the mortar specimens in the tidal pool, and control keys are shown in Fig. 6. In order to simulate the real environmental condition of the south of Iran, the salt concentration of water was set to $38.9 \mathrm{~g}$ per liter, the same as that in the Persian Gulf water, and the temperature and humidity of the interior 
Fig. 6 The interior view of the marine simulator environment
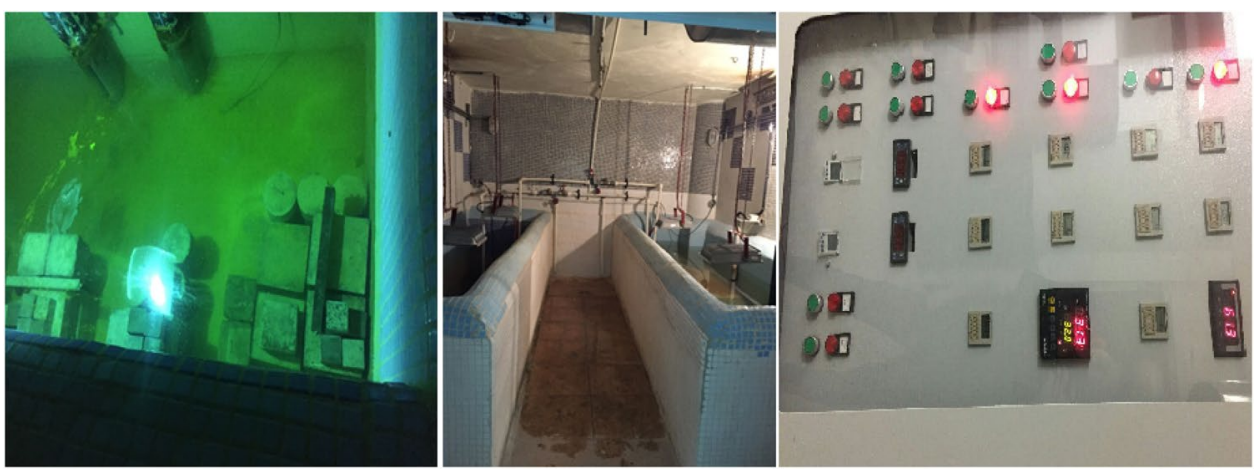

simulator were set regularly by checking the real condition of the test region.

\section{Results and discussion}

\subsection{Compressive strength}

The compressive strength of the mortars, cured in the Persian Gulf environmental condition, at the ages of 7, 28, 56, and 90 days is plotted in Figs. 7 and 8 for cementbased and geopolymer-based mortars, respectively. In the cement-based mortars, the strength development occurred through chemical reactions between major compounds of cement and water, called hydration, while in the geopolymer-based mortars the strength development occurred through the geopolymerization reaction which starts with the dissolution of the minerals from the base materials. The source materials, chemical activator type, and the curing condition are known as the main factors affecting the geopolymerization process [48, 59-62].

As expected, the mean compressive strength of all the mortars increased over time. Also, it is evident from Fig. 9 that the strength development of all the mortars slowed down after the age of 28 days and continued to increase at slower rates until 90 days.

It can be seen that, in cement-based mortars, the mixtures containing pozzolanic materials have developed a noticeable strength at ages beyond 7 days compared to the control OPC specimens. Specifically, at the age of 90 days, the sample containing $30 \%$ slag and $7.5 \%$ of silica fume reached the highest value of compressive strength. The reason for this enhancement is the formation of further gels in the pozzolanic reactions, as well as, the property of silica fume to act as filler which enrich the cohesiveness between precursor materials and aggregates [63].

Further, the mortars containing silica fume showed a higher value of early age compressive strength. This can be attributed to the large specific surface area of silica fume which can accelerate the hydration reaction at
Fig. 7 The compressive strength of cement-based mortars at various ages

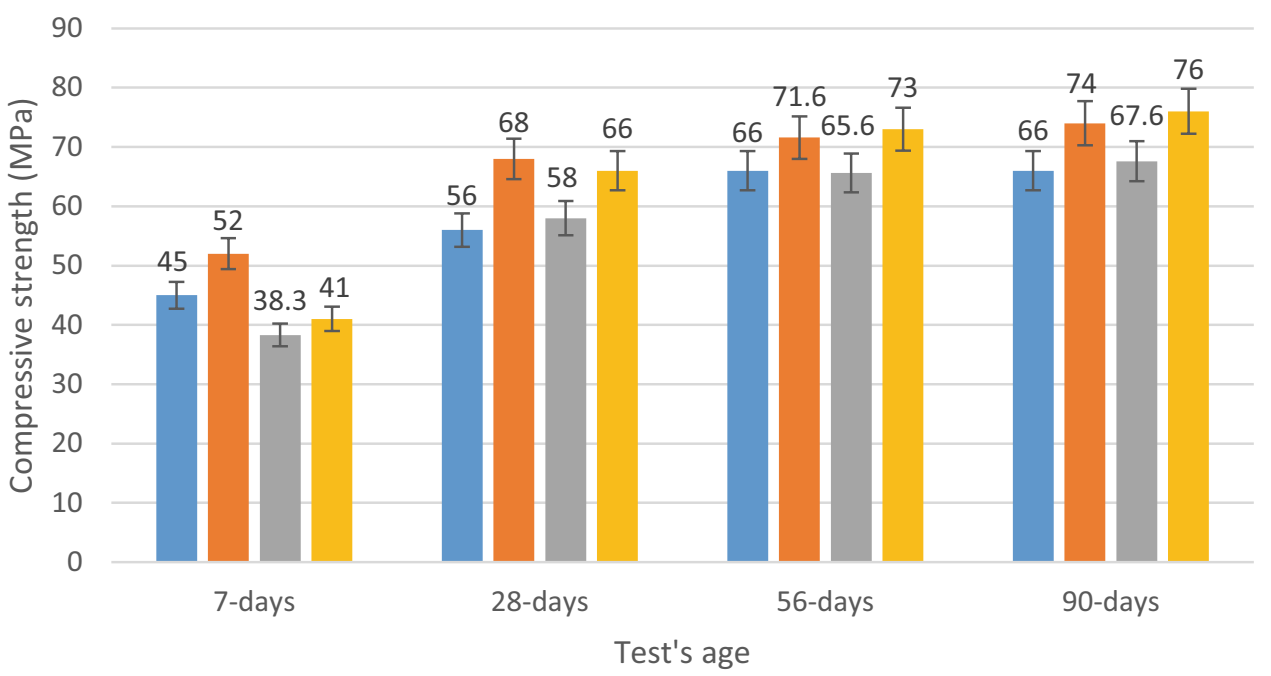

$=\mathrm{OPC} \square 7 / 5 \mathrm{M}=30 \mathrm{~S}=3057 / 5 \mathrm{M}$ 
Fig. 8 The compressive strength of geopolymer-based mortars at various ages
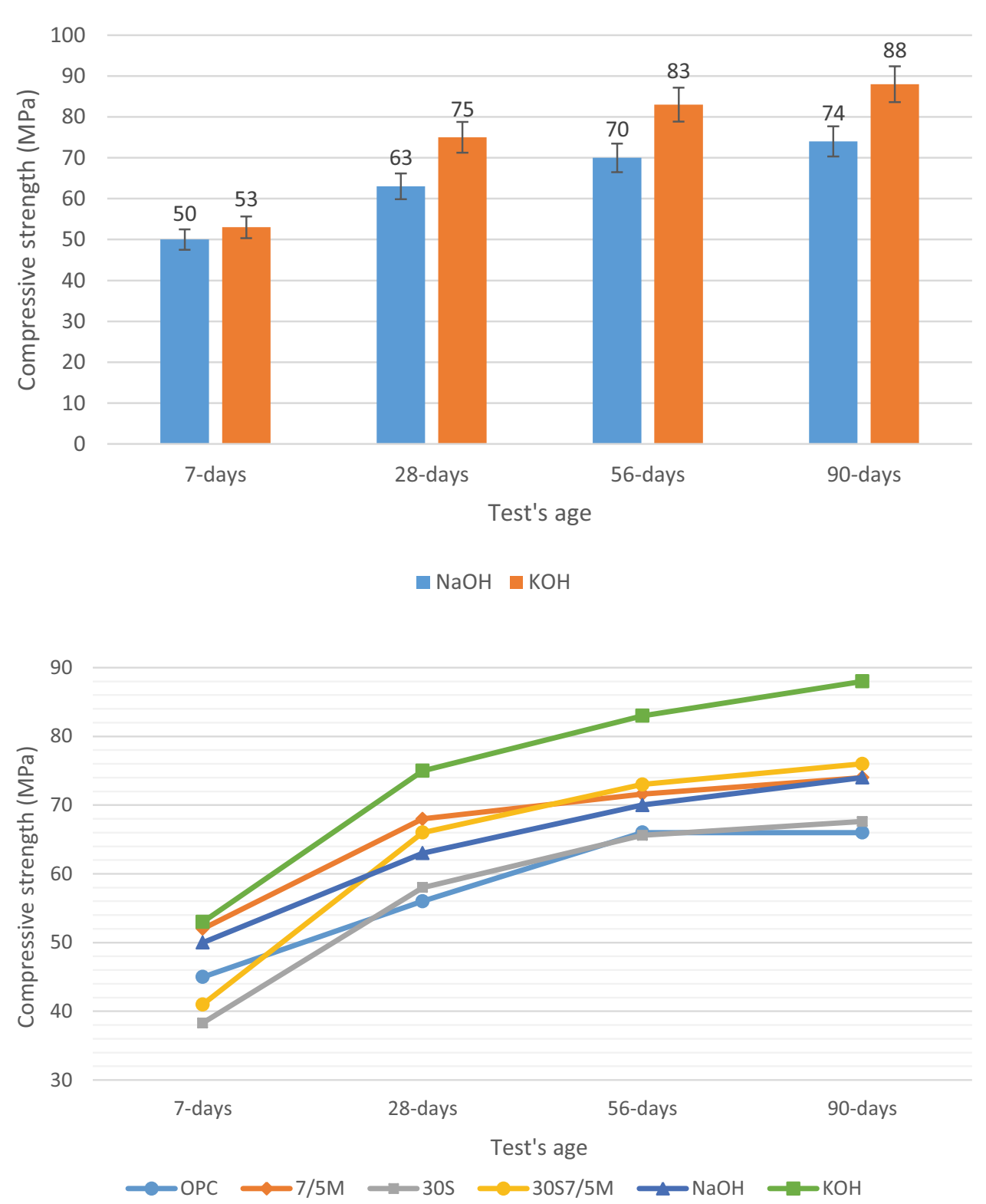

Fig. 9 The compressive strength development of mortars with age early ages $[64,65]$. However, with the increase in age, the samples prepared with slag or combination of slag and silica fume attained higher values of strength due to the long-term hydration of slag. To be more specific, at the age of 7 days, mix 7.5 M and mix 30S7.5 M showed the compressive strengths of 52 and $41 \mathrm{MPa}$, respectively. For the same mixtures, at the age of 90 days, the compressive strength reached $74 \mathrm{MPa}$ and $76 \mathrm{MPa}$, which are $42 \%$ and $85 \%$ increases, respectively.

In the geopolymer-based mortars, compressive strength is influenced by the type of alkaline activator in the mixture [66]. At the same molar concentration (6 M), $\mathrm{KOH}$ mixtures exhibited higher compressive strengths than $\mathrm{NaOH}$. This can be explained by the fact that the $\mathrm{KOH}$ mass incorporated in the $\mathrm{KOH}$ solution is more than the
$\mathrm{NaOH}$ applied in its solution since the molar mass of $\mathrm{KOH}$ and $\mathrm{NaOH}$ is 56 and 40 , respectively [26].

A comparison between geopolymer-based and cement-based mortars indicates that mortars containing $\mathrm{KOH}$ attained higher strengths compared to cement-based mortars at all the ages, which is related to the difference between the nature of geopolymerization and hydration reactions. It should be noted that, all types of mix design in this experiment could meet the minimum requirement of the CCl standard [67] and the Iranian code for durable concrete in Persian Gulf and Oman Sea [28] that define $35 \mathrm{MPa}$ as the minimum compressive strength of concrete and geopolymer structures in the marine environment of the Persian Gulf. 


\subsection{Shear bonding strength}

It can be seen in Fig. 10 that the adhesion strengths of geopolymer mortars at all ages were much higher than the OPC mortar and cement-based mortars. Among the cement-based mortars, mix $3057.5 \mathrm{M}$ and among the geopolymer mortars, mix $\mathrm{KOH}$ showed the highest value of Shear strength. Specifically, compared to the OPC at the age of 90 days, the shear strength of mix $3057.5 \mathrm{M}$ and mix KOH increased about 75 and $104 \%$, respectively.

As it is evident, in the geopolymer-based mortars, the type of alkaline activator is influential in the final shear strength of mix designs at all ages. The higher molar mass of $\mathrm{KOH}$ compared to $\mathrm{NaOH}$ results in the higher mass incorporation of this alkali activator in the $6 \mathrm{M}$ concentration, which can be effective in better shear strength achievement of $\mathrm{KOH}$ mix design [26]. Overall, the results of this experiment are very similar to the results of the compressive strength test, so it may be possible to establish a relationship between compressive strength and shear bond strength.

\subsection{Tensile bonding strength (pull-off test)}

The results derived from the pull-off tests are displayed in Fig. 11. As it is evident, there are minor changes between the strengths of the samples after 7 and 28 days of curing. In this regard, the quick setting and strength development of AAMs may be influential [68].

It can be seen that for the environmental condition of the Persian Gulf, both cement-based and geopolymerbased mortars indicated a higher value of tensile strength compared to the control OPC specimen. Specifically, the mix KOH and mix $\mathrm{NaOH}$ showed $81 \%$ and $66 \%$ increase in the value of tensile strength compared to the control OPC specimen at the age of 28 days. Regarding cement-based specimens, the substitution of Portland cement with pozzolanic materials also led to higher values of tensile
Fig. 10 The shear bonding strength for various coating types

Fig. 11 The tensile bonding strength (Pull-off test) results
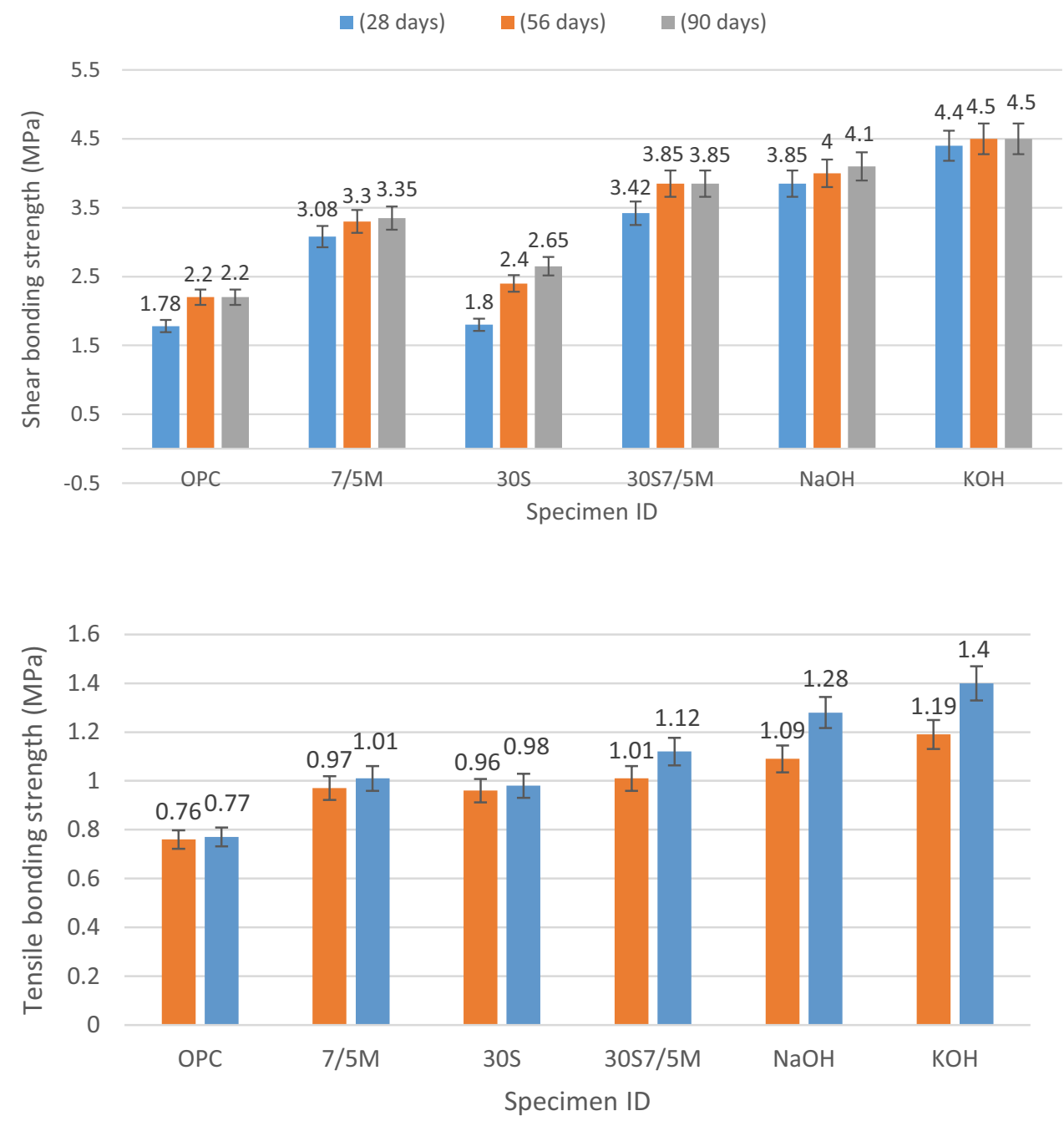

7 days 28 days 
strength. In fact, the mix $3057.5 \mathrm{M}$ gained the highest value followed by mix 7.5 M and 30S, respectively. Accordingly, compared to OPC mix design, the mixes $3057.5 \mathrm{M}$, $7.5 \mathrm{M}$, and $30 \mathrm{~S}$ increased the 28 days tensile strength about 45,31 , and $27 \%$, respectively.

Further, a good correlation can be seen between the pull-off test and compressive strength test results. The same trend was observed in both tests by adding different values and types of pozzolanic materials and producing mortar with geopolymer technology. The formation of further $\mathrm{C}-\mathrm{S}-\mathrm{H}$ gel and filler effect of the pozzolanic materials, as well as, characteristics of the geopolymerization process may be the rational explanation for this observation, as was observed in the previous studies [26].

\subsection{Drying shrinkage (Persian Gulf condition)}

Dimensional stability is another characteristic of a suitable coating mortar. The low shrinkage of repairing mortars is considered as one of the important factors for having dimensional stability in coatings. Indeed, shrinkage can cause shear stress, reduction of adhesion, and eventually premature peeling of the mortar from concrete surface. Therefore, in this research, the drying shrinkage test has been performed on the coating mortars and the weekly results are plotted in Fig. 12. It should be noted that all the steps were performed based on ASTM C596 [55] except that the specimens were not kept in the control room with the ambient temperature. In fact, as the theme of this research was evaluating the geopolymer and cementbased coatings in the aggressive environment of the Persian Gulf, the samples were placed in the marine simulated environment to make the results more compatible with the real conditions of the Persian Gulf. For this goal, all the samples were located in a tidal condition while the temperature and humidity changed hourly based on the weather station reports of the Persian Gulf.

As can be seen in Fig. 12, the geopolymer mortars showed higher values of shrinkage compared to the various types of cement-based mortars. Specifically, the highest shrinkage rate was attributed to the geopolymer-based mortar produced with $\mathrm{KOH}$, while the lowest rate was assigned to the cement-based samples containing $30 \%$ of slag. To justify this matter, it should be noted that, the water is released during the geopolymerization process. This water comes out of the geopolymer matrix during the presence of specimens in the marine simulator environment and curing process. Thus, the shrinkage of specimens can be attributed to this water disposal. On the other hand, the water would be consumed to perform the hydration process. This difference in the nature of the geopolymerization and hydration process can be the reason for more shrinkage of geopolymer mortars in comparison with cement-based ones.

Based on the AS1379-2007 standard, the value of 1000 microstrains $(0.1 \%)$ is recommended as the maximum drying shrinkage for concrete structures. Although OPC, $30 \mathrm{~S}$, and 30S7.5 M samples met this requirement, other specimens showed higher values of shrinkage. To justify this matter, it should be noted that, firstly, the geopolymer specimens are expected to have higher values of shrinkage based on the nature of geopolymerization process, as was mentioned in former paragraph. Secondly, the curing environment of samples in this test (Persian Gulf simulator) was actually a harsh environmental condition compared to the standard condition. During sun exposure, the samples were located above the water level (tides) and the average ambient temperature was between 40 and $45^{\circ} \mathrm{C}$ and the humidity was about 65-70 percent. Losing more water and higher shrinkage of the samples in comparison with the samples in the standard conditions were consequences of
Fig. 12 Drying shrinkage of mortars

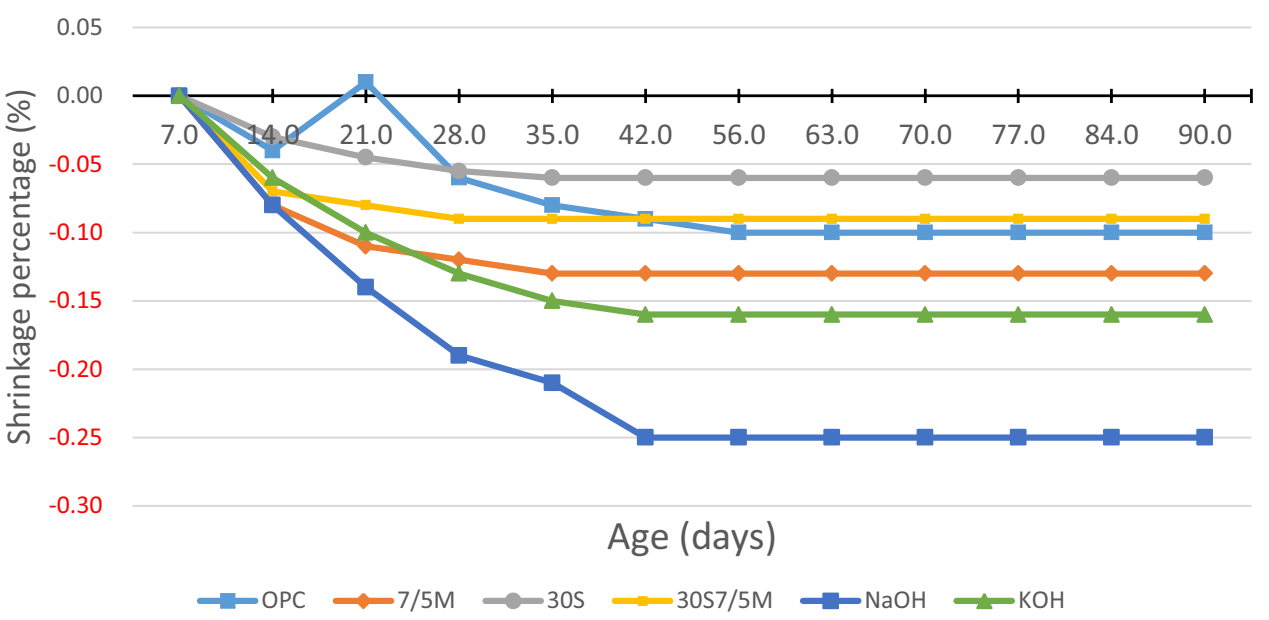

SN Applied Sciences A SPRINGER NATURE journal 
being in a warmer and more humid environment that make the specimens more susceptible to the shrinkage.

\subsection{Rapid chloride migration test (RCMT)}

The coefficient of chloride ions' migration is obtained through this experiment. The higher this coefficient, the higher the possibility of chlorine penetration into concrete or mortar. The results of the experiments and the measured migration coefficients are depicted in Fig. 13.

As it is evident, by increasing the value of cement substitutes, the migration of the chloride ion in the structure of the mortar specimens reduced significantly. Further, the comparison between geopolymer and OPC mortars shows the lower permeability of geopolymer mortar against the chloride migration. This observation can validate the similar results obtained from previous studies that AAMs have shown better performance in terms of chloride resistance compared to the OPC mortars [69-73].
Indeed, slag and silica fume contribute to further gel production and lower porosity of the mortars, which are effective parameters on chloride resistance of the mortars. Besides, silica fume delivers more $\mathrm{Si}_{2}$ to react with $\mathrm{Ca}(\mathrm{OH})_{2}$, producing higher amounts of $\mathrm{C}-\mathrm{S}-\mathrm{H}$ gel, and consequently providing a denser microstructure.

The normalized values of the migration coefficient are also presented in Table 8. For this goal, the migration coefficient of OPC mortars at each age is considered as control value and the normalized quantities of other mix designs are measured based on this assumption. According to the result, the substitution of Portland cement with pozzolanic materials led to fewer migration coefficient of mix designs. Specifically, at the age of 28 days, mixes $7.5 \mathrm{M}, 30 \mathrm{~S}$, and $30 S 7.5 \mathrm{M}$ reduced the chloride coefficient by about 67,79 , and $85 \%$, respectively. In regard to geopolymer coatings, compared to the OPC, mixes $\mathrm{NaOH}$ and $\mathrm{KOH}$ reduced the chloride coefficient about 82 and $78 \%$, respectively. Overall, the combination of slag and silica fume (3057.5 M) was found to be most effective on chloride resistance of mortars at all the test's ages. Further, a criterion [74] is applied
Fig. 13 The chloride ion migration coefficients measured by RCMT

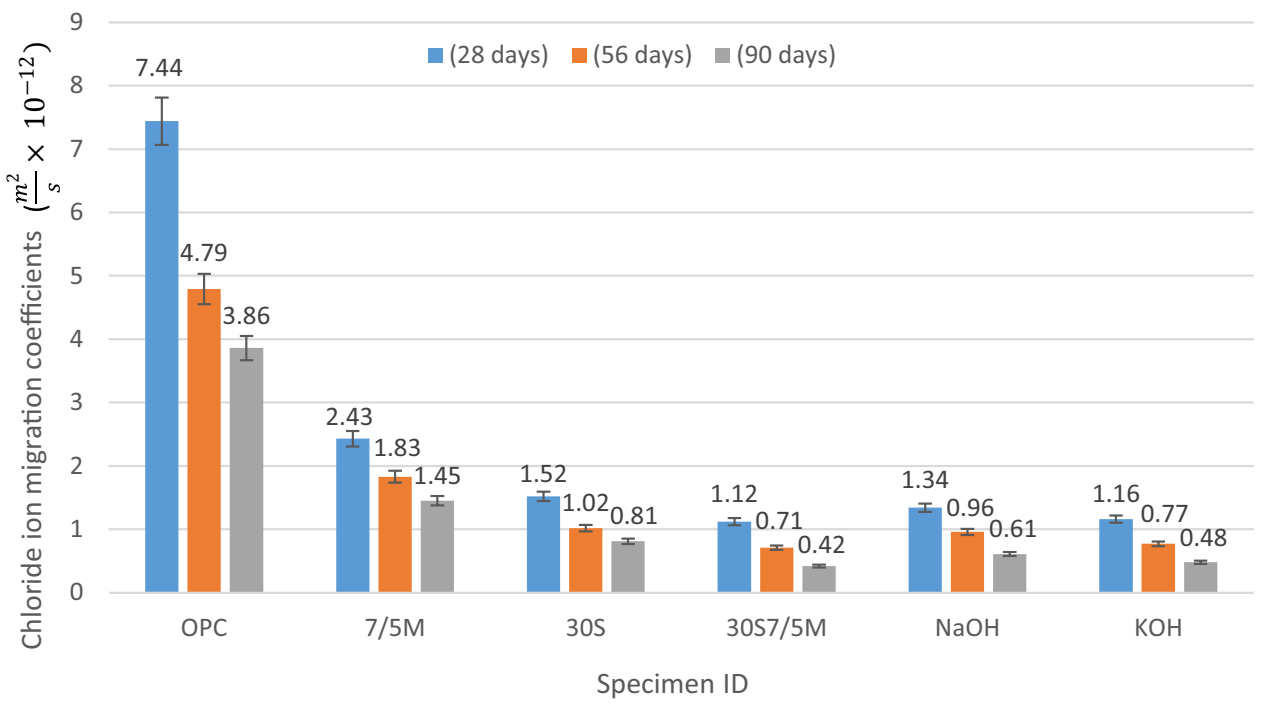

Table 8 Migration coefficients derived from RCMT at different ages up to 90 days

\begin{tabular}{|c|c|c|c|c|c|c|}
\hline Mixture ID & OPC & $7.5 \mathrm{M}$ & $30 S$ & $7.5 \mathrm{M} 30 \mathrm{~S}$ & $\mathrm{NaOH}$ & $\mathrm{KOH}$ \\
\hline 28 days migration Coe. $\left({ }^{*} 10^{-12}\right)$ & 7.44 & 2.43 & 1.52 & 1.12 & 1.34 & 1.6 \\
\hline Normalized migration Coe. 28 days & $0.00 \%$ & $-67.33 \%$ & $-79.57 \%$ & $-84.95 \%$ & $-81.99 \%$ & -78.49 \\
\hline Resistance to chloride penetration [74] & Acceptable & Good & Good & Good & Good & Good \\
\hline 56 days migration Coe. $\left({ }^{*} 10^{-12}\right)$ & 4.79 & 1.83 & 1.02 & 0.71 & 0.96 & 0.77 \\
\hline Normalized migration Coe. 56 days & $0.00 \%$ & $-61.79 \%$ & $-78.71 \%$ & $-85.18 \%$ & $-79.96 \%$ & $-83.92 \%$ \\
\hline Resistance to chloride penetration [74] & Good & Good & Good & Good & Good & Good \\
\hline 90 days migration Coe. $\left({ }^{*} 10^{-12}\right)$ & 3.86 & 1.45 & 0.81 & 0.42 & 0.61 & 0.48 \\
\hline Normalized migration Coe. 90 days & $0.00 \%$ & $-62.44 \%$ & $-79.02 \%$ & $-89.12 \%$ & $-84.19 \%$ & $-87.56 \%$ \\
\hline Resistance to chloride penetration [74] & Good & Good & Good & Good & Good & Good \\
\hline
\end{tabular}


for the quality classification of mortar resistance to the chloride ion penetration, and almost all the mortars are categorized as "good," based on this criterion, although it should be noted that this criterion is not basically established for AAS mortars and it may not be an authentic reference for the quality classification of the mortars in this experiment. It can also be seen that in all samples and mix designs, migration coefficients have decreased over time, which indicates the importance of adequate curing time.

\subsection{Capillary absorption test}

The penetration of water into the capillary spaces inside the concrete and mortar can be an effective factor in the penetration of different ions in addition to the problems stem from freeze-thaw cycles [43]. The infiltration of water into the empty spaces of concrete and mortar is sometimes due to applied forces such as the impact of waves, and sometimes without external forces. One way to determine the degree of water infiltration into the samples is the capillary absorption test, in which water enters the capillary spaces and no applied force to accelerate the test is needed. In this project, the capillary absorption test has been performed, the results of which are presented in Fig. 14.

As can be seen from the diagrams, the amount of water absorption in the control sample of OPC mortar is very high. This amount has been greatly reduced by adding pozzolans to the mixture. For example, in 1-h samples at the age of 90 days, mix 7.5 M, 30S, and 30S7.5 M have reduced the capillary absorption coefficient about 68,58 , and $74 \%$, respectively. It can be due to the production of a secondary gel by cement substitutes that fills capillary spaces during the process and decreases the space for water to penetrate.

Another noteworthy point is the high capillary water absorption coefficient in geopolymer samples. To clarify this matter, it should be noted that based on the ASTM C1585 [57] the samples were placed in the oven at a temperature of 50 degrees for 3 days. These heat treatments cause the formation of micro-cracks and in some cases, the formation of connections between the cracks in geopolymer samples, leading to increased water penetration.

Another important result is that most of the water absorption of geopolymer mortar samples is attributed to the absorption in the first hours, while the later hours are not responsible for much water absorption. The same results were also reported in previous studies $[48,75]$. In other words, if the water absorption is controlled in the early hours, then we can expect low penetration of water into the samples, and thus achieve better durability properties. As it is obvious in Fig. 15 in the mix $\mathrm{NaOH}$ about 63\% of the capillary absorption was obtained at the first hour of the test implementation. The 3-h, 6-h, 24-h, and 72-h measurements showed only $16 \%, 11 \%, 5 \%$, and $5 \%$ of the total water absorption, respectively. On the other hand, in a cement-based sample (mix 30S), the capillary absorption values for the same time intervals are $38 \%, 20 \%, 7 \%, 2 \%$, and $15 \%$, respectively, which indicates less importance of the first hour in the final results.

\section{Conclusion}

This investigation presented a laboratory study to evaluate the durability characteristics and mechanical properties of geopolymer-based and cement-based coating mortars in the harsh environment of the Persian Gulf. Based on the test results, the following significant findings have been derived:

- In tensile adhesion, shrinkage, and rapid chloride migration test (RCMT), the mixtures containing GGBFS showed better performance in the Persian Gulf environment. This can be attributed to the ability of slag to replace a higher percentage of cement compared to the silica fume. In fact, slag has significant ability to fill voids, which is influential in lowering the migration coefficient of chloride ions. On the other hand, in the compressive strength, shear adhesion, and capillary water absorption tests, the mixtures containing silica fume provided better results. The faster onset of pozzolanic activity of silica fume that is due to the nature of this material, its fineness, and high specific surface area is influential in this regard

- In the 3-part mix design containing both slag and silica fume, the pozzolan with faster and more pozzolanic activities (silica fume) plays the task of gaining strength and filling empty spaces in the short term, and the pozzolan with higher replacement capability (slag) produces secondary gel in the long run. Consequently, the use of both pozzolans leads to the superior performance of the mix design of all ages.

- Geopolymer designs have shown better performance compared to cement-based mortars both in terms of strength and compatibility properties. However, their high water absorption rate, especially at young ages can make it difficult to use these mortars in corrosive environments, such as Persian Gulf. This indicates the importance of curing process for geopolymer mortars and concretes, especially at young ages.

- The drying shrinkage results indicated higher values of shrinkage for geopolymer coatings compared to the cement-based ones. This can be attributed to the nature of geopolymerization process, in which the 
Fig. 14 The capillary absorption coefficient at the age of 28 (a), 56 (b), and 90 (c) days

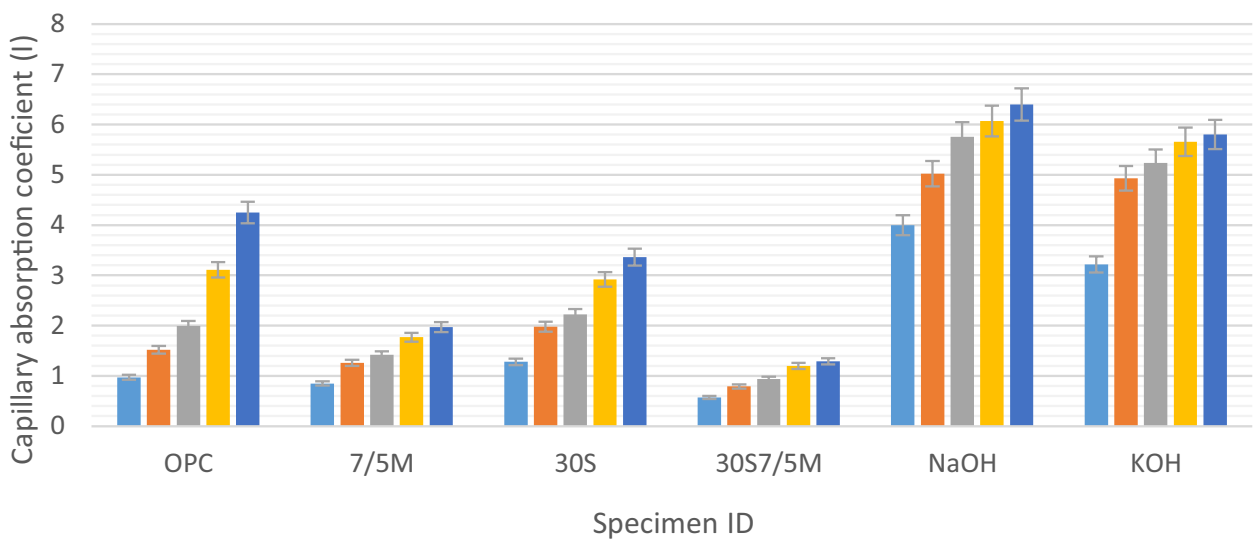

(a)

घhour 13 hour $\quad 6$ hour $\square 24$ hour $\quad 72$ hour

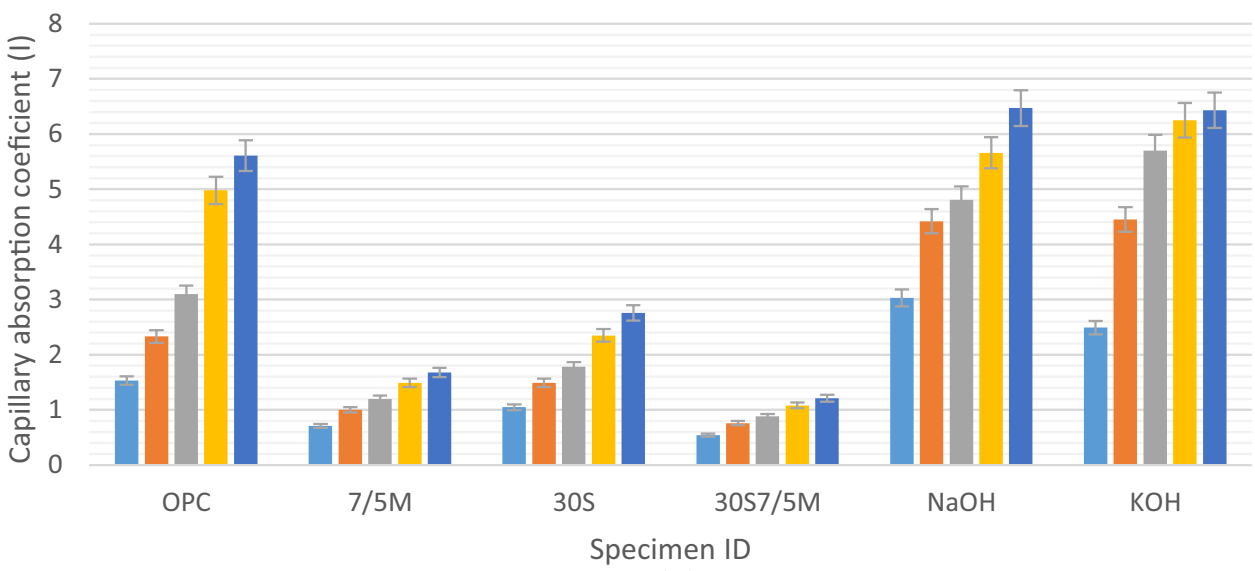

(b)

घhour $\quad 3$ hour $\square 6$ hour $\square 24$ hour $\square 72$ hour

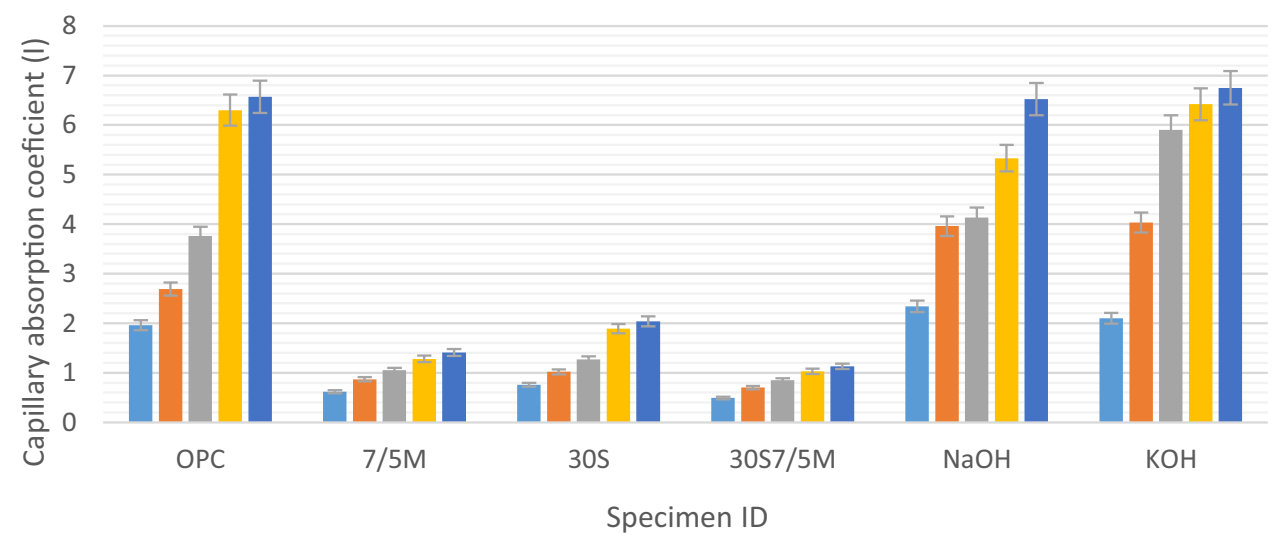

(c)

$\square$ hour $\square$ hour $\quad 6$ hour $\square 24$ hour $\square 72$ hour

water would be released from the geopolymer matrix during the presence of specimens in the Persian Gulf environment.

- The type of alkali activator in geopolymer mortars has a great impact on the mechanical properties and durability of the mix designs. In general, the $\mathrm{KOH}$ solution had superior performance compared to $\mathrm{NaOH}$ solution, and its use can be suggested in the harsh and corrosive environmental condition of Persian Gulf.

Based on the results, cement-based designs containing $30 \%$ slag with $7.5 \%$ silica fume can be selected as the 


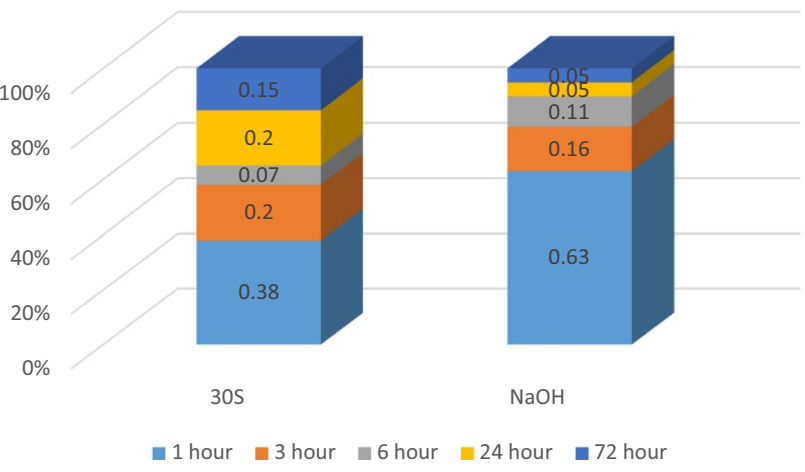

Fig. 15 The hourly/final ratio of capillary absorption coefficient for $\mathrm{NaOH}$ and $30 \mathrm{~S}$ designs (28 days)

optimal design for the environmental conditions of the Persian Gulf meeting mechanical, strength, and Durability requirements. However, the selection of the final design requires consideration of several factors such as available resources, available executive facilities, the severity of the conditions related to the construction site, economic considerations, and environmental necessities.

It should be noted that the infiltration of chloride ions as a destructive factor for reinforced concrete structures was discussed in this study, while in real conditions, the infiltration of chloride and carbonation phenomenon occur simultaneously. Therefore, in order to make a more comprehensive analysis, it is suggested that the combined effects of chloride infiltration and carbonation on coating and repairing mortars in the Persian Gulf conditions be investigated. Also, the repetition of experiments performed on mortars cured in the real environment of the Persian Gulf can be done as a complementary study.

Acknowledgements The authors would like to thank the support from the Concrete Technology and Durability Research Center (CTDRC) at the Amirkabir University of Technology for providing facilities and equipment. Special thanks go to Kandovan Pars Co. for providing required materials to perform this experiment.

\section{Availability of data and material Not applicable.}

\section{Declaration}

Conflict of interest The authors declare that they have no conflict of interest.

Open Access This article is licensed under a Creative Commons Attribution 4.0 International License, which permits use, sharing, adaptation, distribution and reproduction in any medium or format, as long as you give appropriate credit to the original author(s) and the source, provide a link to the Creative Commons licence, and indicate if changes were made. The images or other third party material in this article are included in the article's Creative Commons licence, unless indicated otherwise in a credit line to the material. If material is not included in the article's Creative Commons licence and your intended use is not permitted by statutory regulation or exceeds the permitted use, you will need to obtain permission directly from the copyright holder. To view a copy of this licence, visit http://creativecommons. org/licenses/by/4.0/.

\section{References}

1. Mehta PK (1991) Concrete in the marine environment. United Kingdom

2. Ahmad S (2003) Reinforcement corrosion in concrete structures, its monitoring and service life prediction-a review. Cement Concrete Compos 25(4-5):459-471. https://doi.org/10.1016/ S0958-9465(02)00086-0

3. Angst U, Vennesland (2009) Detecting critical chloride content in concrete using embedded ion selective electrodes-effect of liquid junction and membrane potentials. Mater Corros 60(8):638-643. https://doi.org/10.1002/maco.200905280

4. Bertolini L (2008) Steel corrosion and service life of reinforced concrete structures. Struct Infrastruct Eng 4(2):123-137. https:// doi.org/10.1080/15732470601155490

5. Shi X, Xie N, Fortune K, Gong J (2012) Durability of steel reinforced concrete in chloride environments: an overview. Constr Build Mater 30:125-138. https://doi.org/10.1016/j.conbuildmat. 2011.12.038

6. Pargar F, Dousti A, Shekarchi M (2009) Durability assessment of some concrete structures in Qeshm Island, Persian Gulf EPScrete view project investigating chloride binding in different cement based materials. [Online]. Available: https://www.researchgate. net/publication/257143410.

7. Ludt WB, Morgan L, Bishop J, Chakrabarty P (2018) A quantitative and statistical biological comparison of three semi-enclosed seas: the Red Sea, the Persian (Arabian) Gulf, and the Gulf of California. Mar Biodivers 48(4):2119-2124. https://doi.org/10. 1007/s12526-017-0740-1

8. Valipour M (2009) Evaluation of chloride ion diffusion in reinforced concrete in the Qeshm island environment regarding the application of pozzolanic materials. University of Tehran, Tehran

9. Kashi A, Ramezanianpour AA, Moodi F (2017) Effect of cement based coatings on durability enhancement of GFRP-wrapped columns in marine environments. Constr Build Mater 137:307316. https://doi.org/10.1016/j.conbuildmat.2017.01.119

10. Otieno M (2010) Transport mechanisms in concrete. Corrosion of steel in concrete (initiation, propagation \& factors affecting). Univ Cape T, 83

11. Perkins $P$ (1997) Repair, protection and waterproofing of concrete structures

12. Li G, Yang B, Guo C, Du J, Wu X (2015) Time dependence and service life prediction of chloride resistance of concrete coatings. Constr Build Mater 83:19-25. https://doi.org/10.1016/j.conbu ildmat.2015.03.003

13. Pour-Ali S, Dehghanian C, Kosari A (2015) Corrosion protection of the reinforcing steels in chloride-laden concrete environment through epoxy/polyaniline-camphorsulfonate nanocomposite coating. Corros Sci 90:239-247. https://doi.org/10.1016/j.corsci. 2014.10.015

14. Selvaraj R, Selvaraj M, lyer SVK (2009) Studies on the evaluation of the performance of organic coatings used for the prevention of corrosion of steel rebars in concrete structures. Prog Org Coat 64(4):454-459. https://doi.org/10.1016/j.porgcoat.2008.08.005

15. Aguirre-Guerrero AM, Robayo-Salazar RA, de Gutiérrez RM (2017) A novel geopolymer application: coatings to protect reinforced concrete against corrosion. Appl Clay Sci 135:437-446. https://doi.org/10.1016/j.clay.2016.10.029 
16. Zhang Z, Yao X, Zhu H (2010) Potential application of geopolymers as protection coatings for marine concrete I. Basic properties. Appl Clay Sci 49(1-2):1-6. https://doi.org/10.1016/j.clay. 2010.01.014

17. Zhang Z, Yao X, Wang H (2012) Potential application of geopolymers as protection coatings for marine concrete III. Field experiment. Appl Clay Sci 67-68:57-60. https://doi.org/10.1016/j.clay. 2012.05.008

18. Yi Y, Zhu D, Guo S, Zhang Z, Shi C (2020) A review on the deterioration and approaches to enhance the durability of concrete in the marine environment. Cem Concr Compos 113:103695. https://doi.org/10.1016/j.cemconcomp.2020.103695

19. Ghasemzadeh F, Sajedi S, Shekarchi M, Layssi H, Hallaji M (2014) Performance evaluation of different repair concretes proposed for an existing deteriorated jetty structure. J Perform Constr Facil 28(4):04014013. https://doi.org/10.1061/(asce)cf.1943-5509. 0000496

20. Davidovits PJ (2002) 30 years of successes and failures in geopolymer applications. Market trends and potential breakthroughs. Geopolymer Conf 1-16

21. Duan P, Yan C, Zhou W, Ren D (2016) Development of fly ash and iron ore tailing based porous geopolymer for removal of $\mathrm{Cu}$ (II) from wastewater. Ceram Int 42(12):13507-13518. https:// doi.org/10.1016/j.ceramint.2016.05.143

22. Kong DLY, Sanjayan JG (2010) Effect of elevated temperatures on geopolymer paste, mortar and concrete. Cem Concr Res 40(2):334-339. https://doi.org/10.1016/j.cemconres.2009.10.017

23. Nazari A, Torgal FP (2013) Modeling the compressive strength of geopolymeric binders by gene expression programming-GEP. Expert Syst Appl 40(14):5427-5438. https://doi.org/10.1016/j. eswa.2013.04.014

24. Zhuang XY et al (2016) Fly ash-based geopolymer: clean production, properties and applications. J Clean Prod 125:253-267. https://doi.org/10.1016/j.jclepro.2016.03.019

25. Temuujin J, Minjigmaa A, Rickard W, Lee M, Williams I, van Riessen A (2009) Preparation of metakaolin based geopolymer coatings on metal substrates as thermal barriers. Appl Clay Sci 46(3):265-270. https://doi.org/10.1016/j.clay.2009.08.015

26. Ramezanianpour AA, Moeini MA (2018) Mechanical and durability properties of alkali activated slag coating mortars containing nanosilica and silica fume. Constr Build Mater 163:611-621. https://doi.org/10.1016/j.conbuildmat.2017.12.062

27. ASTM C150/150M-18 (2021) Standard specification for portland cement. Annu. B. ASTM Stand. I, no. April, pp. 1-4, 2018. Accessed 21 Feb 2021. [Online]. Available: https://www.astm. org/Standards/C150.

28. Ramezanianpour A, Science AP (2004) Iranian code for durable concrete in Persian Gulf and Omman Sea. Build Eng Hous Sci J 2

29. ISIRI (2020) Standards and specification for the portland cement-ISIRI NUMBER 389 (8th edition). Accessed 30 Jun 2020. [Online]. Available: https://datis-inc.com/wp-content/uploads/ 2020/07/What-is-ISIRI-389-1.pdf.

30. International A (2011) ASTM C 187-11: standard test method for amount of water required for normal consistency of hydraulic cement paste

31. American Society for Testing and Materials (2021) ASTM C19108 standard test methods for time of setting of hydraulic cement by vicat needle. Annual Book of ASTM Standards 191-04, i. pp 1-8. Accessed 21 Feb 2021. [Online]. Available: https://www. astm.org/Standards/C191.

32. American Society of Testing Materials (2021) ASTM C188-15: Standard test method for density of hydraulic cement. Annu. B. ASTM Stand., vol I, p 3. Accessed 21 Feb 2021. [Online]. Available: https://www.astm.org/Standards/C188

33. ASTM C204 (2021) Standard test methods for fineness of hydraulic cement by air-permeability. ASTM Int. West Conshohocken,
PA, pp 1-10. Accessed 21 Feb 2021. [Online]. Available: https:// www.astm.org/Standards/C204

34. ASTM C109_C109M - 13 Standard Test Method for Compressive Strength of Hydraulic Cement Mortars (Using 2-in." Accessed 21 Feb 2021. [Online]. Available: https://www.astm.org/Standards/ C109

35. ASTM C989/C989M-18a (2018) Standard specification for slag cement for use in concrete and mortars, ASTM International, West Conshohocken, PA. www.astm.org," Accessed 21 Feb 2021. [Online]. Available: https://www.astm.org/Standards/C989.htm

36. ASTM C 1240/C 1240M - 05 (2005) Standard specification for silica fume used in cementitious mixtures. ASTM Int, pp 1-7. Accessed 21 Feb 2021. [Online]. Available: https://www.astm. org/Standards/C1240.

37. Mustakim SM et al (2020) Improvement in fresh, mechanical and microstructural properties of fly ash- blast furnace slag based geopolymer concrete by addition of nano and micro silica. SILICON. https://doi.org/10.1007/s12633-020-00593-0

38. "ASTM C778 - 17 Standard Specification for Standard Sand," vol 03, pp 1-5, 1860, Accessed 21 Feb 2021. [Online]. Available: https://www.astm.org/DATABASE.CART/HISTORICAL/C778-00. htm

39. Bondar D, Lynsdale CJ, Milestone NB, Hassani N, Ramezanianpour AA (2011) Effect of type, form, and dosage of activators on strength of alkali-activated natural pozzolans. Cem Concr Compos 33(2):251-260. https://doi.org/10.1016/j.cemconcomp. 2010.10.021

40. Jafari Nadoushan M, Ramezanianpour AA (2016) The effect of type and concentration of activators on flowability and compressive strength of natural pozzolan and slag-based geopolymers. Constr Build Mater 111:337-347. https://doi.org/10.1016/j. conbuildmat.2016.02.086

41. Khan MNN, Sarker PK (2020) Effect of waste glass fine aggregate on the strength, durability and high temperature resistance of alkali-activated fly ash and GGBFS blended mortar. Constr Build Mater 263:120177. https://doi.org/10.1016/j.conbuildmat.2020. 120177

42. Habert G, D'Espinose De Lacaillerie JB, Roussel N (2011) An environmental evaluation of geopolymer based concrete production: reviewing current research trends. J Clean Prod 19(11):1229-1238. https://doi.org/10.1016/j.jclepro.2011.03.012

43. Visitanupong C (2009) Durability of fly ash based geopolymer mortar. Civ Eng, 178

44. Moeini MA, Bagheri $M$, Joshaghani $A$, Ramezanianpour AA, Moodi $F$ (2018) Feasibility of alkali-activated slag paste as injection material for rehabilitation of concrete structures. J Mater Civ Eng 30(10):04018252. https://doi.org/10.1061/(asce)mt.19435533.0002400

45. Yang KH, Song JK, II Song K (2013) Assessment of $\mathrm{CO}_{2}$ reduction of alkali-activated concrete. J Clean Prod 39:265-272. https:// doi.org/10.1016/j.jclepro.2012.08.001

46. McLellan BC, Williams RP, Lay J, Van Riessen A, Corder GD (2011) Costs and carbon emissions for geopolymer pastes in comparison to ordinary portland cement. J Clean Prod 19(9-10):10801090. https://doi.org/10.1016/j.jclepro.2011.02.010

47. ASTM, "C 1437 - Standard test method for flow of hydraulic cement mortar," 2013. Accessed 21 Feb 2021. [Online]. Available: https://www.astm.org/Standards/C1437

48. Rostami M, Behfarnia K (2017) The effect of silica fume on durability of alkali activated slag concrete. Constr Build Mater 134:262-268. https://doi.org/10.1016/j.conbuildmat.2016.12. 072

49. Sayed M, Zeedan SR (2012) Green binding material using alkali activated blast furnace slag with silica fume. HBRC J 8(3):177184. https://doi.org/10.1016/j.hbrcj.2012.10.003 
50. Singh B, Rahman MR, Paswan R, Bhattacharyya SK (2016) Effect of activator concentration on the strength, ITZ and drying shrinkage of fly ash/slag geopolymer concrete. Constr Build Mater 118:171-179. https://doi.org/10.1016/j.conbuildmat. 2016.05.008

51. Sahmaran M, Yücel HE, Yildirim G, Al-Emam M, Lachemi M (2014) Investigation of the bond between concrete substrate and ECC overlays. J Mater Civ Eng 26(1):167-174. https://doi.org/10. 1061/(asce)mt.1943-5533.0000805

52. Silfwerbrand J (2003) Shear bond strength in repaired concrete structures. Mater Struct 36(6):419-424. https://doi.org/10.1007/ bf02481068

53. Delatte NJ, Wade DM, Fowler DW (2000) Laboratory and field testing of concrete bond development for expedited bonded concrete overlays. ACI Struct J 97(3):272-280. https://doi.org/ $10.14359 / 4622$

54. EN 1542, "Products and systems for the protection and repair of concrete structures. Test methods. Measurement of bond strength by pull-off," 2000. Accessed 21 Feb 2021. [Online]. Available: https://shop.bsigroup.com/ProductDetail?pid=00000 0000019972442.

55. "ASTM Standard C596:2009 'Standard Test Method for Drying Shrinkage of Mortar Containing Hydraulic Cement 1,"' pp. 5-8, 2009, Accessed 21 Feb 2021. [Online]. Available: https://www. astm.org/Standards/C596.

56. Repair C (1999) "NT build 492: concrete, mortar and cementbased repair materials: chloride migration coefficient from nonsteady state migration experiments. Measurement, 1-8

57. ASTM C1585 - Standard Test Method for Measurement of Rate of Absorption of Water by Hydraulic-Cement Concretes. https:// www.google.com/search?q=ASTM+C1585\&oq=ASTM+C1585 \&aqs=chrome..69i57.147j0j9\&sourceid=chrome\&ie=UTF-8. Accessed 21 Feb 2021

58. Kashi A, Ramezanianpour AA, Moodi F, Malekitabar H (2019) Effect of aggressive marine environment on strain efficiency factor of FRP-confined concrete. Constr Build Mater 222:882-891. https://doi.org/10.1016/j.conbuildmat.2019.07.055

59. Bernal SA, Mejía De Gutiérrez R, Pedraza AL, Provis JL, Rodriguez ED, Delvasto S (2011) Effect of binder content on the performance of alkali-activated slag concretes. Cem Concr Res 41(1):1-8. https://doi.org/10.1016/j.cemconres.2010.08.017

60. Jambunathan $\mathrm{N}$ et al (2013) The role of alumina on performance of alkali-activated slag paste exposed to $50 \mathrm{C}$. Cem Concr Res 54:143-150. https://doi.org/10.1016/j.cemconres.2013.09.009

61. Keeley PM, Rowson NA, Johnson TP, Deegan DE (2017) The effect of the extent of polymerisation of a slag structure on the strength of alkali-activated slag binders. Int J Miner Process 164:37-44. https://doi.org/10.1016/j.minpro.2017.05.007

62. Phoo-Ngernkham T, Maegawa A, Mishima N, Hatanaka S, Chindaprasirt P (2015) Effects of sodium hydroxide and sodium silicate solutions on compressive and shear bond strengths of FAGBFS geopolymer. Constr Build Mater 91:1-8. https://doi.org/ 10.1016/j.conbuildmat.2015.05.001
63. Jithendra C, Elavenil S (2020) Effects of silica fume on workability and compressive strength properties of aluminosilicate based flowable geopolymer mortar under ambient curing. SILICON 12(8):1965-1974. https://doi.org/10.1007/s12633-019-00308-0

64. Rao GA (2003) Investigations on the performance of silica fume-incorporated cement pastes and mortars. Cem Concr Res 33(11):1765-1770. https://doi.org/10.1016/S0008-8846(03) 00171-6

65. Uzal B, Turanli L, Yücel H, Göncüoğlu MC, Çulfaz A (2010) Pozzolanic activity of clinoptilolite: a comparative study with silica fume, fly ash and a non-zeolitic natural pozzolan. Cem Concr Res 40(3):398-404. https://doi.org/10.1016/j.cemconres.2009. 10.016

66. Nath P, Sarker PK (2012) Geopolymer concrete for ambient curing condition. Australas Struct Eng Conf 2012 Past, Present Futur Struct Eng, pp 1-9

67. Dr Anvaar E, Dr Amini A, Dr Amir-Ebrahimi F, Mr Esmaeeli AM, Mr Esmaeelpour AM (2004) CONCRETE CODE of IRAN (CCI)

68. Shi C, Krivenko PV, Roy D (2006) Alkali-activated cements and concretes. Taylor \& Francis, Milton Park

69. Ismail I et al (2013) Influence of fly ash on the water and chloride permeability of alkali-activated slag mortars and concretes. Constr Build Mater 48:1187-1201. https://doi.org/10.1016/j. conbuildmat.2013.07.106

70. Ravikumar D, Neithalath N (2013) An electrical impedance investigation into the chloride ion transport resistance of alkali silicate powder activated slag concretes. Cem Concr Compos 44:58-68. https://doi.org/10.1016/j.cemconcomp.2013.06.002

71. Miranda JM, Fernández-Jiménez A, González JA, Palomo A (2005) Corrosion resistance in activated fly ash mortars. Cem Concr Res 35(6):1210-1217. https://doi.org/10.1016/j.cemco nres.2004.07.030

72. Kannapiran K, Sujatha T, Nagan S (2013) Resistance of reinforced geopolymer concrete beams to acid and chloride migration. Asian J Civ Eng 14(2):225-238

73. Kupwade-Patil K, Allouche EN (2013) Examination of chlorideinduced corrosion in reinforced geopolymer concretes. J Mater Civ Eng 25(10):1465-1476. https://doi.org/10.1061/(asce)mt. 1943-5533.0000672

74. Tang L, Nilsson L-O (1996) A numerical method for prediction of chloride penetration into concrete structures. In: The modelling of microstructure and its potential for studying transport properties and durability. Springer, Netherlands, pp 539-552

75. Robayo-Salazar R, Jesús C, Mejía R, de Gutiérrez F, PachecoTorgal F (2019) Alkali-activated binary mortar based on natural volcanic pozzolan for repair applications. J Build Eng. https:// doi.org/10.1016/j.jobe.2019.100785

Publisher's Note Springer Nature remains neutral with regard to jurisdictional claims in published maps and institutional affiliations. 